\title{
First derivative potentiometric and spectrophotometric determinations of cimetidine in tablets
}

\author{
Benjamin U. EBESHI*, Edebi VAIKOSEN and Dougha TUMA \\ Department of Pharmaceutical and Medicinal Chemistry, Faculty of Pharmacy, Niger Delta University, PMB \\ 071, Wilberforce Island, Bayelsa State, Nigeria. \\ *Corresponding author; E-mail: ben.beshi@gmail.com; Tel: +234-8059817538
}

\begin{abstract}
Cimetidine is an imidazole derivative, which acts as $\mathrm{H}_{2}$-receptor antagonist to inhibit gastric acid secretion and is thereby useful in the treatment of ulcers and other hyperacidity stomach disorders. This study sets out to provide simple, inexpensive and sensitive analytical techniques for the assay of cimetidine in tablet dosage forms using first derivative potentiometric and UV-spectrophotometric techniques, with a view to providing simple, sensitive and cost-effective analytical methods. Ten brands of cimetidine tablets were purchased from pharmacies in Yenagoa and Port Harcourt, Niger Delta region of Nigeria. The samples were assayed by Potentiometric and UV spectrophotometric methods after a Thin Layer Chromatographic (TLC) fingerprint. The potentiometric assay results of the samples ranged from $92-100 \%$ of stated amount for $70 \%$ of the samples. The coefficient of variation for In-between run, Intra-day run and accuracy of the UV spectrophotometric method was within $3 \%$. The percentage purity of cimetidine from UV determination at 260 $\mathrm{nm}$ ranged from $86-97 \%$, showing that $50 \%$ of the samples conformed to the stated standard - ie: contain 95 $105 \%$ of stated amount. The TLC fingerprints of the samples were similar in many respects, including $\mathrm{R}_{\mathrm{f}}$ values which ranged from 0.8 to 0.9 compared to the reference sample with $R_{f}$ value of 0.9 . The results suggest that either of the two methods can be fine-tuned for assay of cimetidine in tablet formulations.

(c) 2013 International Formulae Group. All rights reserved.
\end{abstract}

Keywords: Potentiometry, ultraviolet (UV) spectrophotometry, analytical methods, cimetidine, Tablet Formulations, volumetric standard (VS).

\section{INTRODUCTION}

Proliferation of substandard and adulterated pharmaceutical products is a global phenomenon, which has been of great concern to many countries including Nigeria. The resurgence of substandard drug products especially, in Nigeria is as a result of a number of factors, which include poor drug procurement and distribution, low literacy level, inadequate information on the circulation of substandard products, lack of facilities for effective quality control analysis as an important element in quality surveillance and ineffectiveness of drug regulatory authorities (Clarke, 2002). These problems have being further compounded in Nigeria that imports most drugs from Asian countries like China and India. The World Health Organisation (WHO) rose to the challenge by recommending that all importing countries should protect themselves from this menace by undertaking sampling of products 
within the distribution network as an important element in quality surveillance (WHO, 1996).

Cimetidine, a $\mathrm{H}_{2}$-receptor antagonist is an imidazole. The full name is: 2-Cyano -1methyl -3-[2-S-methyl imidazole -4- yl methyl thio] ethyl guanidine (Figure 1). It acts as $\mathrm{H}_{2-}$ receptor antagonist and inhibits gastric acid secretion, being particularly effective against the nocturnal acid secretion (Harvey and Champe, 2009).

It acts by competitively blocking the binding of histamine to $\mathrm{H}_{2}$ - receptors. It binds selectively to the histamine- $\mathrm{H}_{2}$-receptor on the basolateral membrane of the parietal cells. Cimetidine inhibits acetylcholine and gastrin mediated acid responses (Brown, 2003). It reduces the intracellular concentration of cAMP, ie: cyclic adenosine monophosphate (Harvey and Champe, 2009). Cimetidine is active against duodenal ulcer, benign gastric ulcer, recurrent stomach ulceration, oesphageal reflux disease and other condition where reduction of gastric acid is beneficial.

A variety of methods both official and non-official have been used to analyze raw cimetidine and cimetidine formulations. A quantitative method using silica gel HPLC plate with fluorescent indicator, automated sample application and UV absorptions developed for the determination of cimetidine have been reported. The method was precise with precision range of $1.2 \%-2.2 \%$ relative standard deviation and the error in the standard additional analysis was $0.985 \%$ compared to the fortification level (ColinJones et al., 1985). Although the authors emphasized the sensitivity of the HPLC method over other techniques including potentiometric method, which is the BP method, they acknowledge the demerit of high cost and complexity of operations involved.

The potentiometric titration method using $\quad 0.1 \mathrm{M}$ perchloric acid (VS) is economical, easily available and it is one of the official methods for the analysis of cimetidine (BP 2008). This method avoids the interference of the excipients since the completion of the reaction is detected through the slope change of the electromotive force (EMF) or the $\mathrm{pH}$ versus the volume of the titrant. Thus, potentiometric titration and UV spectrophotometric methods are suitable for cimetidine analysis. A $0.1 \mathrm{M}$ perchloric acid $\mathrm{VS}$ is one whose actual concentration is accurately determined.

\section{MATERIALS AND METHODS \\ Materials}

Cimetidine reference standard (SigmaAldrich, USA), glacial acetic acid (BDH), perchloric acid (BDH), sulphuric acid, distilled water, crystal violet and distilled water, methanol (Sigma Aldrich), and ethylacetate (BDH). Ten brands of cimetidine of tablet were procured from Pharmacies in Yenagoa and Port-Harcourt, Niger Delta Region of Nigeria and were coded A to $\mathrm{J}$. Their batch and official registration (NAFDAC) numbers and the address of the manufacturer for each brand as well as their corresponding manufacturing and expiry dates were duly documented.

\section{Equipment}

These include analytical weighing balance (Galenkamp), burettes, UV spectrophotometer (Shimadzu, Japan), measuring cylinder, potentiometer (Galenkamp), volumetric flask, beakers, pipettes, conical flask, retort stands, TLC plates and iodine tank.

\section{Methods \\ Weight uniformity test}

Ten tablets (10) of samples A to J were accurately weighed one after the other using an analytical balance and the respective weights were recorded. The average weights, weight variation, standard deviation and percentage deviation of the respective brands were calculated.

\section{Thin layer chromatography}

Cimetidine $(0.5 \mathrm{~g})$ was dissolved in 10 $\mathrm{ml}$ of methanol, which is used as the sample solution. $1 \mathrm{ml}$ of this was pipetted and 
methanol was added to make exactly $10 \mathrm{ml}$, which is used as the standard solution. Each of the sample solution and the standard solution was spotted on a TLC plate. After much trials in developing the solvent system in ratios, ratios such as ethylacetate: methanol; (50:50), ethylacetate methanol (70:30), ethylacetate: methanol (60:40), the TLC plate was developed with a mixture, of ethylacetate and methanol in the ratio $(80: 20)$ to a distance of $15 \mathrm{~cm}$. The plate was air dried and then dried in the ovum at $80{ }^{\circ} \mathrm{C}$ for about 30 mins. The plate was allowed to stand mix with iodine vapour for 45 mins. The distance moved by the sample and the distance moved by the solvent were measured.

\section{Potentiometric titration}

The $\mathrm{pH}$ meter was standardized against a buffer solution of $\mathrm{pH}$ 4. Powdered cimetidine tablet $(0.276 \mathrm{~g})$ was weighed and then dissolved in $60 \mathrm{ml}$ of acetic acid in a volumetric flask. A burette was filled with $0.1 \mathrm{M}$ perchloric acid. The $\mathrm{pH}$ of the drug was first determined then, perchcloric acid (0.1M) was added in drops and it was stirred with each dropping into the beaker and $\mathrm{pH}$ change was noted. As there was an increase in $\mathrm{pH}$, the amount of titrant added was reduced to $0.5 \mathrm{ml}$, this was followed by a sharp drop in the $\mathrm{pH}$ indicating nearness to the endpoint. This procedure was repeated for all the other samples. A graph of the mean $\mathrm{pH}$ of the solution was plotted against the volume of titrant for samples A to $\mathrm{J}$ to determine the equivalence point.

\section{U.V Spectrophotometric analysis}

Preparation of cimetidine standard stock solution

$500 \mathrm{mg}$ of standard cimetidine was weighed and transferred into a beaker were it was dissolved with $0.1 \mathrm{M} \mathrm{H}_{2} \mathrm{SO}_{4}$ and filtered. The resultant solution was transferred into a $50 \mathrm{ml}$ volumetric flask and it was made up to mark with $0.1 \mathrm{M} \mathrm{H}_{2} \mathrm{SO}_{4}$ solution to give a stock concentration of $10 \mathrm{mg} / \mathrm{ml}$. A portion of the solution was scanned between 220-350 nm.

\section{Calibration curve for cimetidine}

From the stock solution $(10 \mathrm{mg} / \mathrm{ml})$ of cimetidine, serial dilutions were made in aqueous $0.1 \mathrm{M} \mathrm{H}_{2} \mathrm{SO}_{4}$ to give the following concentrations; $1 \mathrm{mg} / \mathrm{ml}, 2 \mathrm{mg} / \mathrm{ml}, 4 \mathrm{mg} / \mathrm{ml}, 6$ $\mathrm{mg} / \mathrm{ml}, \quad 8 \mathrm{mg} / \mathrm{ml}$ and $10 \mathrm{mg} / \mathrm{ml}$. The absorbance of these concentrations were measured and recorded at $260 \mathrm{~nm}$. The graph of absorbance was plotted against the concentration using Microsoft excel 2007 version.

\section{Preparation of test sample}

A weight equivalent to $500 \mathrm{mg}$ of powdered cimetidine test sample A was weighed and transferred into a beaker were it was dissolved with some $0.1 \quad \mathrm{M} \mathrm{H}_{2} \mathrm{SO}_{4}$ solutions and filtered. The resultant solution was transferred into a $50 \mathrm{ml}$ volumetric flask and it was made up to mark with $0.1 \mathrm{M} \mathrm{H}_{2} \mathrm{SO}_{4}$ solution to give a stock concentration of 10 $\mathrm{mg} / \mathrm{ml}$. From the prepared stock solution, concentrations of $1 \mathrm{mg} / \mathrm{ml}$ and $10 \mathrm{mg} / \mathrm{ml}$ were prepared using a micro-pipette and there UV absorbance was measured at the $\lambda_{\max }$ of 260 $\mathrm{nm}$. This procedure was repeated for brands B to $\mathrm{J}$. The absorbance was extrapolated on the calibration curve and the percentage content of each of the test samples was calculated.

\section{Statistical analysis}

Student t-test in the SPSS statistical software programme was used to compare the UV spectrophotometric and potentiometric methods assay results in this study with $\mathrm{p}<$ 0.05 as the level of significance.

\section{RESULTS \\ Uniformity of weight}

The percentage deviation of each tablet from the average weight for the samples A-J ranged from approximately -2.5 to $2.2 \%$. 


\section{Thin layer chromatographic method}

The $R_{f}$ value, which is calculated as the ratio of the distance moved by drug sample against the distance moved by the solvent front of the reference standard of cimetidine and the test samples A to $\mathrm{J}$ are shown in Table 1.

\section{Potentiometric titration of cimetidine tablets samples A to J}

The equivalence point of the potentiometric titrations of cimetidine samples A to $\mathrm{J}$ were determined graphically by a plot of the $\mathrm{pH}$ changes against the volume of titrant. Figure 2 shows a representative graph of the mean $\mathrm{pH}$ changes against volume of titrant while Figure 3 indicates the First derivative potentiometric graph for samples A to J. The \% purity for samples A-J were calculated by dividing the equivalence point of each sample by the equivalence point of reference standard multiplied by a 100 as shown in Table 2.

Figure 4 shows a chart indicating a comparative result of potentiometric titrations and UV spectrophotometric method for the assay of cimetidine tablets samples A to J.

\section{UV-spectrophotometric method Standard curve for cimetidine}

The calibration curve for the standard ciprofloxacin was linear over a concentration range of 1.0 to $10 \mathrm{mg} / \mathrm{ml}$ with the regression line equation obtained as $y=0.085 x+0.031$, which was in line with the Beer-Lambert's law.

\section{Precision of the analytical method}

The coefficient of variation, which is a measure of the precision, was $<2 \%$ for Inbetween run and was $<3 \%$ for the Intra-day run, which is a measure of reproducibility of the method for cimetidine (Table 3). Also, the relative error (\%), an indicator of accuracy was within $3 \%$.

\section{Percentage purity for cimetidine test samples}

The percent purity of samples A to $\mathrm{J}$ was calculated using the regression equation obtained from the standard curve by UV spectrophotometry is shown in Table 4. Samples A-J showed \% purity, which ranged from 85.5 to $97.3 \%$ with the highest \% deviation of approximately $3 \%$ from the mean of all the samples.

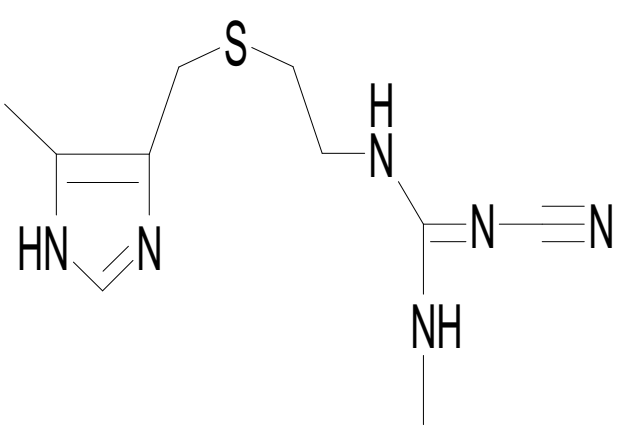

Figure 1: Chemical structure of cimetidine 
Table 1: $T L C \mathrm{R}_{\mathrm{f}}$ values of standard cimentidine and test samples A to $\mathrm{J}$.

\begin{tabular}{cccc}
\hline Samples & Distance moved by solvent & Distance move by the drug & $\mathbf{R}_{\mathbf{f}}$ \\
\hline A & 6.0 & 5.4 & 0.9 \\
B & 6.0 & 5.4 & 0.9 \\
C & 6.0 & 5.4 & 0.9 \\
D & 6.0 & 5.4 & 0.9 \\
E & 6.0 & 5.2 & 0.8 \\
F & 6.0 & 5.0 & 0.8 \\
G & 6.0 & 5.4 & 0.9 \\
H & 6.0 & 5.4 & 0.9 \\
I & 6.0 & 5.2 & 0.8 \\
J & 6.0 & 5.0 & 0.8 \\
\hline
\end{tabular}

Table 2: Percentage purity for samples A to $\mathrm{J}$ following potentiometric titration.

\begin{tabular}{ccc}
\hline Sample & Volume of titrant $(\mathbf{m l})$ & \% Purity \\
\hline A & 7.92 & $100.0 \%$ \\
B & 7.90 & $99.70 \%$ \\
C & 7.40 & $93.40 \%$ \\
D & 7.90 & $99.7 \%$ \\
E & 7.92 & $100.0 \%$ \\
F & 7.30 & $92.2 \%$ \\
G & 7.40 & $93.4 \%$ \\
H & 7.90 & $99.7 \%$ \\
I & 7.91 & $99.9 \%$ \\
J & 7.92 & $100.0 \%$ \\
\hline
\end{tabular}

Table 3: Precision and accuracy studies for cimetidine $(n=5)$.

\begin{tabular}{cccc}
\hline & $\begin{array}{c}\text { Expected } \\
\text { conc. }(\mathbf{m g} / \mathbf{m l})\end{array}$ & $\begin{array}{c}\text { Observed mean } \\
\text { conc. } \pm \text { SD }(\boldsymbol{\mu g} / \mathbf{m l})\end{array}$ & Coefficient of variation (\%) \\
\hline In-between run & 1.0 & $1.05 \pm 0.014$ & 1.33 \\
& 5.0 & $4.92 \pm 0.058$ & 1.18 \\
Intra-day run & 10.0 & $9.85 \pm 0.056$ & 0.57 \\
\hline \multirow{2}{*}{ Accuracy } & 1.0 & $0.98 \pm 0.025$ & 2.55 \\
& 5.0 & $5.05 \pm 0.047$ & 0.93 \\
& 10.0 & $9.68 \pm 0.082$ & 0.87 \\
\hline
\end{tabular}


Table 4: Percentage purity of cimetidine samples A to J.

\begin{tabular}{|c|c|c|c|c|c|c|}
\hline \multirow{2}{*}{$\begin{array}{l}\text { Sample } \\
\text { code }\end{array}$} & \multicolumn{2}{|c|}{ Absorbance } & \multicolumn{2}{|c|}{$\begin{array}{l}\text { Observed conc. } \\
(\mathrm{mg} / \mathrm{ml})\end{array}$} & \multirow{2}{*}{$\begin{array}{c}\text { Mean } \\
\text { Observed } \\
\text { conc. } \\
(\mathrm{mg} / \mathrm{ml})\end{array}$} & \multirow{2}{*}{$\begin{array}{l}\text { Percentage } \\
\text { purity }(\%)\end{array}$} \\
\hline & $1 \mathrm{mg} / \mathrm{ml}$ & $10 \mathrm{mg} / \mathrm{ml}$ & $1 \mathrm{mg} / \mathrm{ml}$ & $10 \mathrm{mg} / \mathrm{ml}$ & & \\
\hline $\mathrm{A}$ & 0.103 & 0.867 & 0.85 & 9.84 & 5.35 & 97.3 \\
\hline B & 0.102 & 0.851 & 0.84 & 9.65 & 5.25 & 95.5 \\
\hline $\mathrm{C}$ & 0.103 & 0.778 & 0.85 & 8.79 & 4.82 & 87.6 \\
\hline $\mathrm{D}$ & 0.1 & 0.852 & 0.81 & 9.66 & 5.24 & 95.3 \\
\hline $\mathrm{E}$ & 0.103 & 0.865 & 0.85 & 9.81 & 5.33 & 96.0 \\
\hline $\mathrm{F}$ & 0.102 & 0.851 & 0.84 & 9.65 & 5.25 & 95.5 \\
\hline $\mathrm{G}$ & 0.1 & 0.861 & 0.81 & 9.76 & 5.29 & 96.2 \\
\hline $\mathrm{H}$ & 0.102 & 0.762 & 0.84 & 8.6 & 4.72 & 85.8 \\
\hline I & 0.102 & 0.862 & 0.84 & 9.78 & 5.31 & 96.5 \\
\hline $\mathrm{J}$ & 0.101 & 0.76 & 0.82 & 8.58 & 4.7 & 85.5 \\
\hline
\end{tabular}

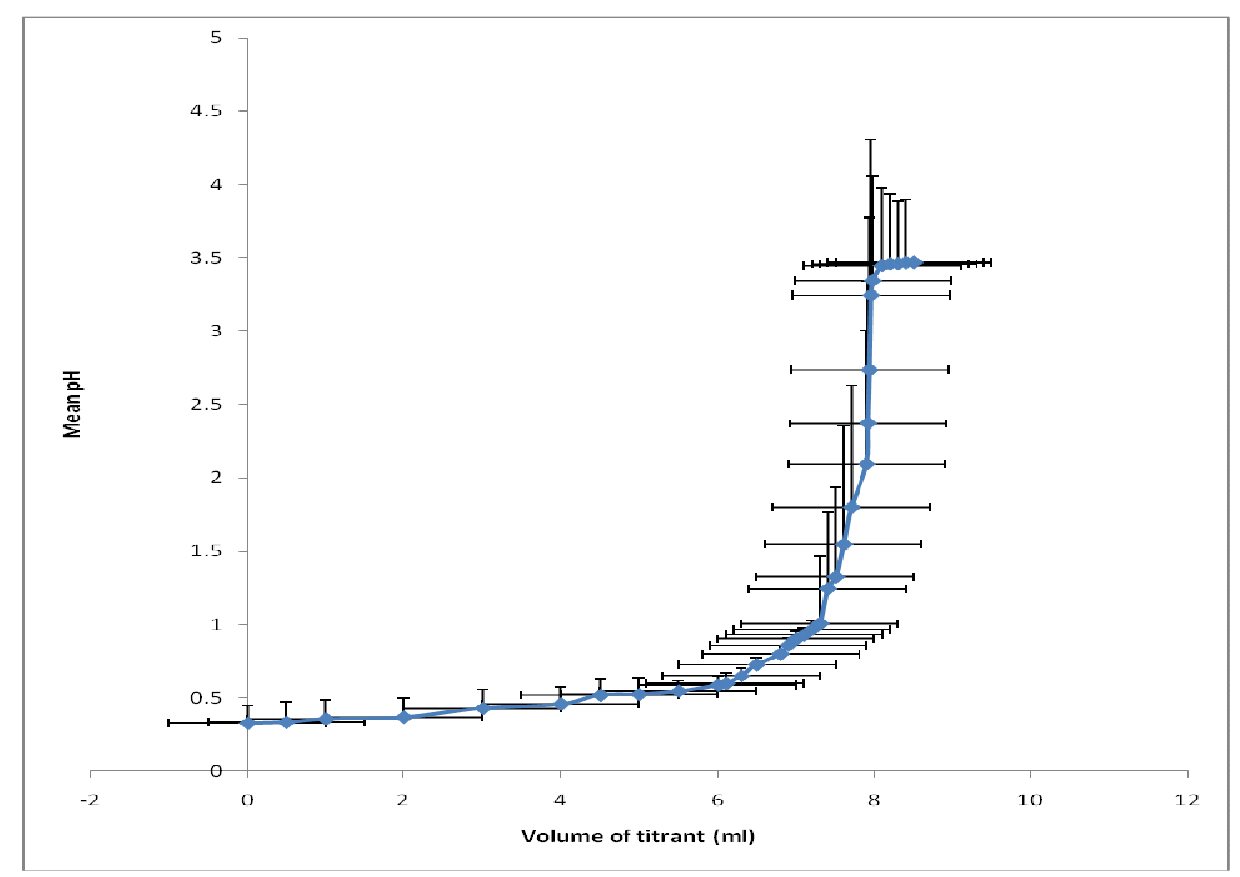

Figure 2: Mean potentiometric titration curve for sample A to $\mathrm{J}$. 


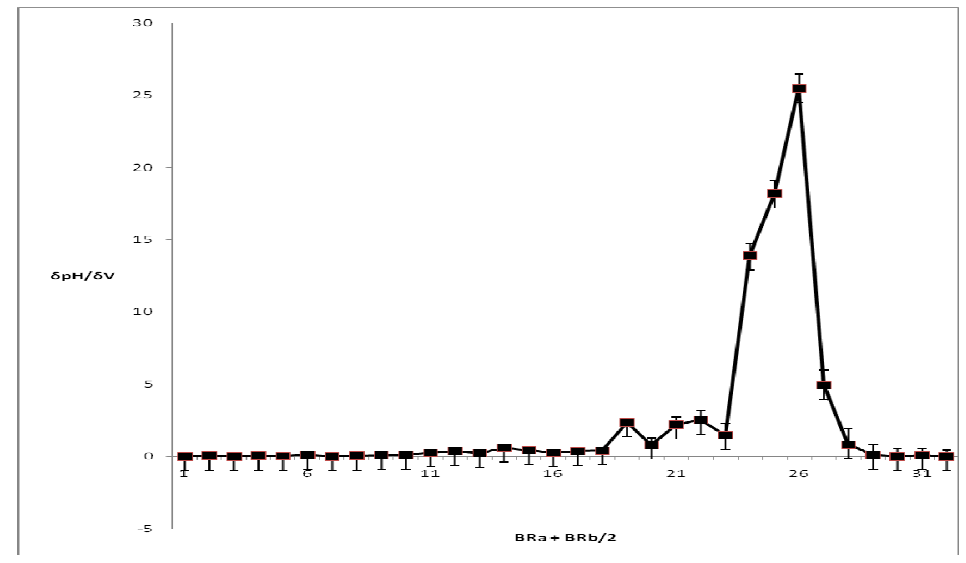

Figure 3: First derivative potentiometric titration curve for samples A to J.

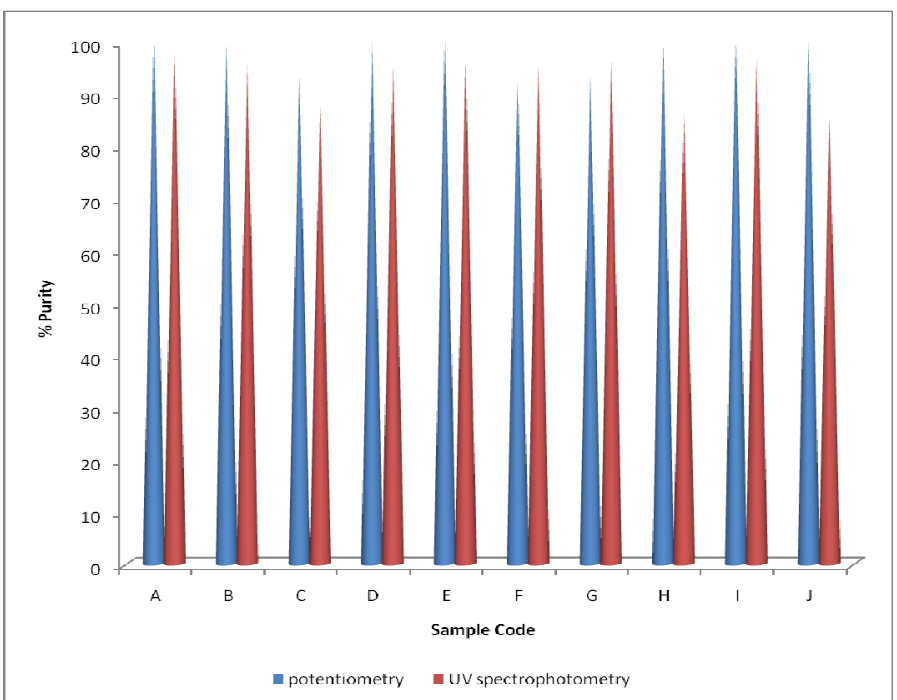

Figure 4: A chart of assay results using potentiometry and uv-spectrophotometry for cimetidine tablets samples A to J.

\section{DISCUSSION}

Potentiometric and UV spectrophotometric were employed in analyzing ten different brands of cimetidine tablet in this study to ascertain that the products contain the required amount of the active ingredients and to investigate the possibility that passing or failing a quality control analysis by a pharmaceutical preparation may result from the inefficiency or limitation of the analytical method used.

The weight uniformity test carried out showed that all the brands of cimetidine passed the test, with no sample exceeding the $\pm 5 \%$ deviation, as specified in the official compendia (USP, 2006; BP, 2008). The TLC fingerprint for the respective brands showed elution, colour change, change in size of 
principal spot and $\mathrm{R}_{\mathrm{f}}$ values ranging from 0.8 0.9. When compared with reference standard that gave $R_{\mathrm{f}}$ value of 0.9 , all the samples fell within the range $\leq 0.9$ point.

In potentiometric titration, the potential of an indicator electrode is measured as a function of the volume of the titrant. The equivalence point of the reaction is shown by a sudden change in the potential. This is shown by the plot of the $\mathrm{pH}$ reading against the volume of titrant (Figure 2). In situations where the change in EMF or $\mathrm{pH}$ is not sharp at the end point, it is difficult to determine it accurately. Therefore, to determine the end point more precisely, a plot of first derivative curve, $\delta \mathrm{pH} / \delta \mathrm{v}$ against $\mathrm{BR}_{\mathrm{a}}+\mathrm{BR}_{\mathrm{b}} / 2$. Where, $\delta \mathrm{pH}$ represents change in $\mathrm{pH}$ on addition of $\delta \mathrm{v}$ $\mathrm{ml}$ of titrant $\left(\delta \mathrm{v}=\mathrm{BR}_{\mathrm{a}}+\mathrm{BR}_{\mathrm{b}}\right) ; \mathrm{BR}_{\mathrm{b}}$ is burette readings before addition of a small volume of a titrant and $\mathrm{BR}_{\mathrm{a}}$ is burette readings after addition of a small volume of titrant. The accuracy of the plots and calculations in potentiometric titrations are enhanced by using small, constant volumes of the titrant during titration, especially near and after the end point as shown in Figure 3. Potentiometric assay result of cimetidine tablet samples ranged from 92.2-100\%, which indicates that $70 \%$ of the samples conformed to the stated limit of 96-105\% (BP, 2008). Samples C, F and G had values slightly below the lower limit of the required range.

The standard cimetidine was scanned within the UV-VIS region for the maximum wavelength $\left(\lambda_{\max }\right)$ of absorption, which was found to be $260 \mathrm{~nm}$. This $\chi_{\max }$ of cimetidine made it possible to monitor the concentrations of cimetidine in the test samples with little or no interference. The calibration curve was linear over the concentration range of $1 \mathrm{mg} / \mathrm{ml}$ to $10 \mathrm{mg} / \mathrm{ml}$ and the regression coefficient $\left(\mathrm{R}^{2}=0.992\right)$ allowed for accurate determination of the concentration and hence percent purity of test samples A to J. The coefficient of variation (\%), an indicator of precision and the relative error (\%), a measure of accuracy of the analytical method, which were evaluated by replicate analyses of the pure drug solution at three different concentrations within working range, indicates high precision and accuracy of the method. The intra-day precision, which is a measure of the reproducibility of the method with coefficient of variation being less than $3 \%$ shows that the method was highly reproducible. The spectrophotometric method was therefore sensitive and reproducible.

The assay of samples A-J by UV spectrophotometric method gave results ranging from $85.5-97.3 \%$, which shows that not all the samples were within the BP limits. Samples C, $\mathrm{H}$ and $\mathrm{J}$ with \% purity of $87.6 \%$, $85.8 \%$, and $85.5 \%$, respectively, are far below the lower required limit of $95 \%$ and could be said to be substandard while samples D and F with $\%$ purity of $95.3 \%$ and $95.5 \%$, respectively were slightly less than the lower required limit, which may result from experimental limits. Overall, 50\% of the cimetidine tablet samples assayed using the UV method had \% purity within the stated official requirement. The findings of suboptimal amount and overage in the test samples may stem from under incorporation of active ingredient, poor formulation, poor storage facilities since presence of chromophores in drug substances makes them light sensitive, adulteration and possible inefficiency of the UV spectophotometer.

Comparing the potentiometric and spectrophotometric methods, it was observed that samples $\mathrm{C}$ and $\mathrm{F}$ failed to meet the stated requirement for both methods while sample $G$ passed the uv spectrophotometric assay it failed to meet the stated standard using potentiometric analysis (Figure 4). However, TLC fingerprint, a useful tool in identifying of the active ingredient of a drug formulation did not justify these findings. The finding in this study shows that potentiometry, and UV spectrophotometry though relatively inexpensive and simple compared to HPLC assay method (Colin-Jones et al., 1985) could be effective in the determination of the quality of active ingredients in cimetidine tablet. 


\section{Conclusion}

Authenticity of pharmaceutical products is measured based on the compliance with official standards as stated in monographs. As far as identification and assay of cimetidine tablet are concerned, this study proved that TLC and any of the two analytical methods (potentiometry and spectrophotometry) can be applied to evaluate the quality of cimetidine tablet formulations.

\section{REFERENCES}

Aymard JP, Aymard B, Netter P, Streiff F, Trechot P, Bamnwarth B. 1988. Heamatological adverse effects of histamine, $\mathrm{H}_{2}$-receptor antagonist. Med. Toxicol., 4: 430-448.

Bardhan KD, Royston C, Beresford J, Mccloy RF, Arnold R, Catlan D, KlinkenbergKnol E, Maton PN, Riddel RH, Sippomen P, Walan A. 1990. Safety of longterm cimetidine treatment. A multicenter study in the UK, Gut., 30: A5599.

British P. 2008. Monographs on Medicinal and Pharmaceutical Substances. Her Majesty's Stationery office. London, 1: 534-537.

Clarke S. 1986. Isolation and Identification of Drugs ( $2^{\text {nd }}$ edn), London Pharmaceuticals Press: London, UK; 261.

Clarke S. 2002. A case study and report presented at the Global Forum on Pharmaceutical Counterfeiting held in Geneva.

Colin-Jones DG, Lungman MJS, Lawson D. H, Vessey MP, Muscroft TJ, Youngs DJ, Birdon DW, Keighley MR. 1985. Post marketing survelliance of the safety of cimetidine, 12 months morbidity report. $Q$. J. Med., 54: 253-268.

Emdex. 2010. The Complete Drug Formulary for Nigeria's Health Professionals. Ed Anti-infective drugs. Lindoz Books Int'l 6040 Montovideo Road, Unit 48: Mississauga, Canada; 256.

Feldman F, Cohen MM. 1982. Intraocular pressure and $\mathrm{H}_{2}$ receptor antagonist. Lancet, 1: 1359.
Garcia-Rodrigwez LA, Wallander MA, Stricker BH. 1997. The risk of acute liver injury associated with cimetidine and other acid suppressing antiulcer drugs, Dr J clin pharmacol, Centre of investigation pharmacoepidemiology; University of Madrid Spain, 183-188.

Harvey RA, Champe DC. 2009. Lipincotts Illustrated Reviews; Pharmacology $\left(4^{\text {th }}\right.$ edn). Wolter's Kluwer: New Delhi, India; 331-332.

Hughes DG, Dowling E A, De Meersman RE, Garnett WR, Kares HT. 1989. Cardiovascular effects of $\mathrm{H}_{2^{-}}$receptor antagonist. J. Clin. Pharmacol., 29(5): 427-429.

Lin JH. 1991. Pharmacokinetic and pharmacodynamics properties of $\mathrm{H}_{2}$ receptor antagonist; Relationship between intrinsic potency and effective plasma concentration. Clin. Pharmacokinet., 220. 218-236.

Ritcher JM, Graham PH, Colditz A, Daniel M. A, Huse M, Thomas BA, Delea E, Gerry Oster DMD. 1989. Cimetidine and adverse reactions: A meta-analysis of randomized clinical trials of short term therapy. Amer. J. Med., 87(3): 278-284.

Robinson TJ, Mulligan TO. 1977. Cimetidine and mental confusion. Lancet, 11: 719.

Shinn AF. 1992. Clinical relevance of cimetidine drug interaction: Drug safety, 7: 245-267.

Somogyi A, Gugler R. 1983. Clinical pharmacokinetic of cimetidine. Clin. Pharmacokinet, 8: 463-495.

USP (United States Pharmacopeia). 2006. United States Pharmacopieal Convention, 12601, Twin brooks Parkway, Rockville, MD 20852, 1756-1757.

WHO. 1996. Guidelines on Import Procedures for Pharmaceutical Products. WHO Technical report series, No. 853. 